\title{
The Role of Technology Entrepreneurship Education in Encouraging to Launch New Ventures
}

\author{
Gheorghe MILITARU \\ University Politehnica of Bucharest, Bucharest, Romania \\ gheorghe.militaru@upb.ro \\ Massimo POLLIFRONI \\ University of Turin, Turin, Italy \\ massimo.pollifroni@unito.it \\ Cristian NICULESCU \\ University Politehnica of Bucharest, Bucharest, Romania \\ cristian.niculescu@upb.ro
}

\begin{abstract}
Technology entrepreneurship refers to processes by which entrepreneurs use resources, and technical systems through collaborative exploration and experimentation to pursue opportunities. The purpose of this study is to explore the role of technology entrepreneurship to increase the intention and motivation of engineering students to establish and manage sustainable new ventures and commercialization of technologies developed in university laboratories. Quantitative data were collected via a questionnairebased by investigating whether engineering students have sufficient entrepreneurial skills to evaluate opportunity, developing new products, and recognizing potential market applications. Engineering students need to be able to exploit opportunities that rely on scientific and technical knowledge to create and capture value by launch new venture. Our important findings have a series of important practical implications for managers, engineering students, engineers, and scientists interested in encouraging economic growth. For example, technology entrepreneurship education increases the intention to start a business and stimulates the activities in a group setting and a network context because of increasing global competition based on agility, creativity and innovation. The findings of the study also provide practical implications suggest that increasing engineering students understanding and awareness of entrepreneurship lead to greater levels of interest in entrepreneurship careers.
\end{abstract}

Keywords: technology entrepreneurship, education, engineering students, new ventures

\section{INTRODUCTION}

Entrepreneurship is based on strategic thinking and risk-taking behaviour that results in the 
creation of new opportunities and economic growth (Schermerhorn, J.R., 2013). Practically, it is the process of discovering new ways of combining resources and capabilities to create value. Entrepreneurship is one of the major engines of economic growth through the creation of new venture. Entrepreneurial ventures also play a key role in developing the business environment through creation of new venture and encouraging entrepreneurship and the acquisition of business skills (Rasmussen and Roger, 2006).

The role of universities in society is changing quickly. They need to provide a collaborative and incentive atmosphere for technology development and business creation. Universities are expected to play a new role in society by the formation of human capital and economic transformations. They can contribute to develop the entrepreneurship through education of engineering students and commercialization of research because students receive knowledge and capabilities through an education process (Militaru, 2015). Entrepreneurship education is a driver for future growth and it is becoming more accepted and applied in most European countries, including Romania. For example, in Romania, the entrepreneurial potential is not fully exploited yet. Entrepreneurship skills can be taught because business training is effective to start a new venture. They are essential for the formation, survival and growth of a new business. Advanced knowledge-intensive skills provide the basis for a business's dynamic capabilities (Militaru, 2015).

Despite the fact that many universities develop the entrepreneurship education programs, little is known about the impact on engineering students' entrepreneurial competences and intentions to launch new ventures. Indeed, previous research has focused on entrepreneurship education whereas a little attention has been given to technology entrepreneurship (Gross, 2005). Higher education organizations contribute to the development of entrepreneurial talent among young graduates.

The purpose of this study is to extend our understanding of the role of technology entrepreneurship education on the intention of engineering students to start new ventures. Technology entrepreneurship education plays a critical role in orienting and developing future engineering students and young entrepreneurs, by providing them the skills, knowledge and capabilities to lunch and manage new business ventures (Dutta et al., 2011). This research also aims to enhance our understanding of how engineering students may benefit from entrepreneurship education. The results of the study have important implications for academic staff, students, researchers, policy makers, as well as prospective entrepreneurs.

Next follows a literature review and hypotheses development. Then a section is dedicated to test our model and hypotheses on data collected from respondents. Next section provides details about the empirical results. Finally, a concluding section presents implications, limitations, and directions for future research.

\section{THEORY DEVELOPMENT AND HYPOTHESES}

Entrepreneurship is a disruptive process that sustains innovation efforts, redistribute the resources and bring greater efficiency for businesses (Chiles et al. 2007). For example, a technology entrepreneurship program needs to encourage initiative and develop in each 
engineering student a positive attitude to the creation of wealth. Fostering technology entrepreneurship generates wealth, job creation and local development.

The existing companies need to attract engineers with capabilities in developing innovative technologies as well as commercializing these technologies. Technology-intensive new ventures are more likely to be initiated by engineering graduates. They have knowledge and skills of technology in a specific field and should be able to identify, create, and exploit new business opportunities (Menzies and Paradi, 2002). Education program in engineering must provide students with diverse learning experiences tools and skills to identify and exploit opportunities, formulate problems, to think creatively and work collaboratively. They will learn how to identify and create new opportunity for new venture or helping to improve the existing businesses.

Technical universities can transform student's passion for technology into an ability to deliver inspired innovation. This type of university yields research results in marketoriented innovation processes and inspires an entrepreneurial spirit in all university areas. Engineering programs provides students a background in the fundamentals of engineering and give their engineering skills and technical ability to develop products, prepares and conducts experiments, or makes prototypes of newly designed equipment. Technical universities stimulate and facilitate technical entrepreneurial through excellence in engineering education. We thus propose:

H1: Education program in engineering is positively related to the venturing rate of engineering students

Technological skills increasingly need to be complemented by entrepreneurial competencies. Business and entrepreneurship skills, competencies and capability of engineering students need to become entrepreneurs for creating and running new business ventures or innovative projects in existing firms. Engineering students need to gain core knowledge of management, finance, marketing and entrepreneurship. Technology entrepreneurship involves taking a new technology development idea and finding a highpotential commercial opportunity to capitalize on it. Thus, engineering students or graduates can transform ideas into business for a particular technology by setting the resources and matching it to the right business model. Creating value requires vision and an ability to identify the customer needs, minimize the potential risks and maximize engineering students or graduates potential to launch new ventures. Therefore, it is hypothesized:

H2: Education program in engineering is positively related to education program in technology entrepreneurship

Technology entrepreneurship education is essential to provide the skills, knowledge and the individual's ability to turn ideas into action. It includes creativity, innovation and risk taking, as well as the ability to launch new ventures. Great ideas remain captive in the heads of students, and the ideas that are developed are not the best fit with business model (Anthony et al. 2014). Thus, students gain a solid core of business skills and given the 
opportunity to capitalize their technical skills. Engineering student who have taken a course in technology entrepreneurship have a higher determination to launch their own business or to do so more quickly after graduation (Menzies and Paradi, 2002). The technology entrepreneurship is an effective way to increase the venturing rate of engineering students or graduates. On the basis of the above discussion, the following hypothesis is proposed:

H3: Education program in technology entrepreneurship is positively related to the venturing rate of engineering students

To reduce the variance caused by other factors, we controlled for the age of respondents and their revenues. The conceptual framework is shown in Figure 1. Relationships among the constructs were empirically tested as follows.

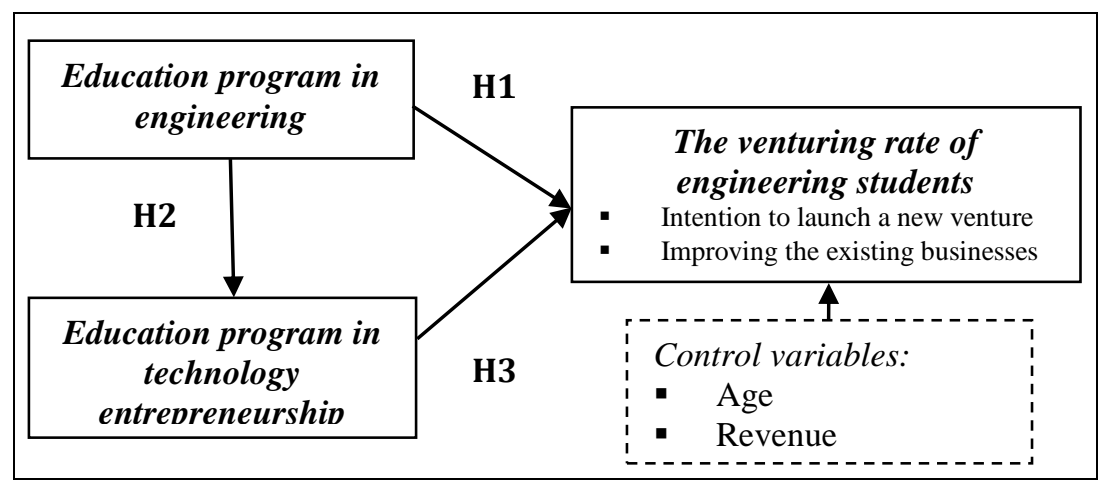

Figure 1: Conceptual framework

\section{RESEARCH DESIGN}

In this section the hypotheses formulated above will be tested about the constructions that influence the venturing rate of engineering students. It was used the regression analysis to test the hypothesized influence of technology education program and technology entrepreneurship on the venturing rate of engineering students.

\section{Questionnaire design and data collection}

For this study was used cross-sectional data from a survey on the venturing rate of engineering students to launch a new venture or to improve the existing business where they will work after graduation. It was generated a structured questionnaire based on observations, studies, ideas that were obtained both on literature and practice. This study is based on a survey administrated to a sample of 28 engineering students. The sample consisted of undergraduate and graduate students from the Faculty of Entrepreneurship, Business Engineering and Management, Politehnica University of Bucharest. The survey was carried out in 2014, and the response rate was 90 percent. No significant differences 
were found between early and late respondents on any of the variables from this study. The confidentiality of the respondents was maintained and no identification was requested from them in the survey.

\section{Measurement}

This study analyzes the causal relationships among the following constructs: education program in engineering, technology entrepreneurship and the venturing rate of engineering students. A rigorous study of literature for identifying existing measures to the related constructs was done to finalize questionnaire. Using questionnaire, students were asked about their technical and business skills gain in bachelor and master programs. Questions focused on determining whether they have knowledge and skills to generate a new technology idea, finding a higher-potential commercial opportunity of this idea, create and verify a business model for how to sell and market an entrepreneurial idea and create and verify a plan for gathering resources such as capital and talent to capitalize the technology opportunity. Student's perceptions in this study were measured with seven-point Likerttype scales with anchors of 1 to indicate "strongly disagree" and 7 to indicate "strongly agree". Seven-point Likert scales indicate the respondents' levels of agreementdisagreement with each statement.

The dependent variable is the venturing rate of engineering students. This variable was measured by using two items - intention to launch a new venture and contribution to improving the existing businesses. Education program in engineering is modelled as an independent variable formed by two factors that measures the ability of students to create knowledge and use of technology for engineering problem-solving, as well as the possibility that they develop their technical skills. Education program in technology entrepreneurship is measured by using five items that referred to create, identify, and evaluate new venture opportunities; defining target customer and value proposition; develop business plans; design a sound business model; start and building a successful company.

To collect the data, students were administrated the scales referring to the following aspects: age of respondents and revenue. Thus, the following control variables were considered age of respondent and students' revenue.

\section{DATA ANALYSIS AND RESULTS}

Table 1 presents the means, standard deviations, and correlation coefficients of all the variables used in this study. There are a few correlations with coefficients above 0.4. To ensure that these moderate correlations are no problem in our research, we calculated variance inflation factors (VIF) for a test of multicollinearity. It shows how much the variance of the estimated coefficient increases if the predictors are correlated. The results were below 5, which does not justify concerns about multicollinearity (Urbig et al. 2013). Since Cronbach's alpha is an indicator of how well the individual items reflect a common, underlying construct, and it is an appropriate measure for validity of the scale items and assessing the reliability of the scale. Cronbach's alpha values were all above 0.7 , indicating a high internal consistency of measure reliability. Composite reliability for all constructs 
were above the suggest threshold of 0.7 , indicating that our measurement was reliable (Nunnally, 1978).

Table 1: Descriptive statistics - correlation coefficients matrix

\begin{tabular}{|l|c|c|c|c|c|c|c|}
\hline & Mean & S.D. & F1 & F2 & F3 & F4 & F5 \\
\hline $\begin{array}{l}\text { The venturing rate of } \\
\text { engineering students (F1) }\end{array}$ & 2.76 & 0.49 & 1.00 & & & & \\
\hline $\begin{array}{l}\text { Education program in } \\
\text { engineering (F2) }\end{array}$ & 0.29 & 1.41 & 0.37 & 1.00 & & & \\
\hline $\begin{array}{l}\text { Education program in } \\
\text { technology } \\
\text { entrepreneurship (F3) }\end{array}$ & 1.26 & 0.54 & 0.45 & 0.41 & 1.00 & & \\
\hline Age (F4) & 21 & 2.1 & 0.32 & 0.38 & 0.07 & 1.00 & \\
\hline Revenue (F5) & 0.86 & 0.5 & 0.18 & 0.36 & 0.23 & 0.17 & 1.00 \\
\hline
\end{tabular}

In a hierarchical analysis, Model 1 estimates a baseline model of controls. Models 2 and 3 are designed to investigate direct and indirect (interaction) effects. Model 3 is a full model that includes all interactions effects. The standardized regression coefficients and results of regression analysis are reported in Table 2.

Table 2: Results of regression analysis $(n=28)$

\begin{tabular}{|c|c|c|c|}
\hline Variable & Model 1 & Model 2 & Model 3 \\
\hline \multicolumn{4}{|l|}{ Control variables: } \\
\hline - Age & $-.02(.06)$ & $-.04(.07)$ & $-.09(.14)$ \\
\hline - Revenue & $.09(.16)$ & $.09(.11)$ & $-.06(.12)$ \\
\hline \multicolumn{4}{|l|}{ Direct effects } \\
\hline - Education program in engineering & & $.08(.16)$ & $.11(.19)$ \\
\hline $\begin{array}{l}\text { Education program in technology } \\
\text { entrepreneurship }\end{array}$ & & $.89(.52)^{* *}$ & $.81(.58)^{* * *}$ \\
\hline \multicolumn{4}{|l|}{ Interaction terms: } \\
\hline $\begin{array}{l}\text { - } \quad \text { Education program in engineering } \\
\mathbf{x} \text { Education program in } \\
\text { technology entrepreneurship }\end{array}$ & & & $.89(.54)^{* *}$ \\
\hline $\mathbf{R}^{2}$ & .183 & .251 & .261 \\
\hline $\mathbf{R}^{2}$ (Adjusted) & .96 & .213 & .381 \\
\hline$\Delta \mathbf{R}^{2}$ & - & $.11 *$ & $.062 *$ \\
\hline
\end{tabular}

$* \mathrm{p}<.05 ; * * \mathrm{p}<.01$ and $* * * \mathrm{p}<.001$ (two-tailed) 
The individual reliability of the constructs was estimated with $\mathrm{R}$ square. $\mathrm{R}$ square is the multiple coefficient of determination and it indicates how well a model fits the data. A significant $\mathrm{R}$ square change here indicates that education program in engineering and education program in technology entrepreneurship interact to influence the venturing rate of engineering students. The adjusted $\mathrm{R}$ square is used to compare models with different numbers of predictors as our case. To test Hypothesis 1, we examine whether education program in engineering has a positive and significant effect on the venturing rate of engineering students. Thus, Hypothesis 1 proposes that there is a direct relationship between education program in engineering and the venturing rate of engineering students. The results of the regression analysis show that Hypothesis 1 must be rejected. Therefore, we failed to find evidence that education program in engineering significantly affects the venturing rate of engineering students. Although the respondents of the education program in engineering had an average age of 21 years, they thought that entrepreneurship skills did not matter at all or that it was not closely related to the technical skills.

Hypothesis 2 propose that education program in engineering is a good driver for the engineering students to attend an education program in technology entrepreneurship. Thus, on the basis of our results we accept this hypothesis. As expected, education program in technology entrepreneurship offering complementary skills in business to engineering students to identify and create new opportunity for new venture or helping to improve the existing businesses.

Finally, on the basis of study results, Hypothesis 3 has been accepted, this states that the education program in technology entrepreneurship significantly affect the venturing rate of engineering students. This hypothesis implies that the education program in technology entrepreneurship catalyse engineering students to launch new ventures or improving the existing businesses. The confirmation of Hypothesis 3 is similar to give engineering students the opportunity to gain entrepreneurial skills by providing such an education program.

\section{CONCLUSION}

In this study we investigate the influence of education program in engineering and education program in technology entrepreneurship on the venturing rate of engineering students. In order to explore this influence, three hypotheses are formulated. Based on the survey results findings confirm hypotheses 2 and 3, and reject 1 . The empirical results indicate that education program in engineering has neither a positive nor a significant influence on the venturing rate of engineering students. A possible explanation may reside in the lack of entrepreneurial skills. The interaction between education program in engineering and education program in technology entrepreneurship lead to improve significantly the engineering students' potential to launch a new venture using entrepreneurial skills gained in the education program in technology entrepreneurship. The technology entrepreneurship education plays an important role in a dynamic economy. It includes creativity, innovation and risk taking, as well as the ability of engineering students to launch new ventures. An integrated approach of these education programs is essential for technical universities. 
Together, these results underscore the importance of education program in technology entrepreneurship for technical universities. They also extend prior research by including the simultaneous effects of education program in engineering and education program in technical entrepreneurship. Technical universities can transform student's passion for technology into an ability to deliver inspired innovation. The results support prior findings regarding the importance of technology entrepreneurship program to encourage initiative and develop in each engineering student a positive attitude to the creation of wealth. Technology entrepreneurship involves taking a technology idea and finding a highpotential commercial opportunity to capitalize on it.

This empirical study has several limitations that provide direction for future research. First, study focuses on a university from a single country and a single time period, as such the results should be generalized with caution. A second limitation of this study lies in the fact that it focuses exclusively on perception of students on the topics treated. Family environment from which the engineering student comes might also be investigated.

\section{REFERENCES}

Anthony, D.S.B., Duncan, D.S., \& Siren, P.M.A. (2014), Build an Innovation Engine in 90 Days. Harvard Business Review, December, 61-68.

Chiles, T.H., Bluedorn, A.C., \& Gupta, V.K. (2007). Beyond creative destruction and entrepreneurial discovery: A radical Austrian approach to entrepreneurship. Organization Studies, 28(4), 467-493.

Dutta, D.K., Li, J. \& Merenda, M. (2011). Fostering entrepreneurship impact of specialization and diversity in education. International Entrepreneurship and Management, 7, 163-179.

Gross, D. (2005). Schumpeter's legacy? Interaction and emotions in the sociology of entrepreneurship. Entrepreneurship Theory and Proactive, 29(2), 205-218.

Menzies, T., \& Paradi, J.C. (2002). Encouraging technology-Based Ventures: Entrepreneurship Education and Engineering Graduates. New England Journal of Entrepreneurship, 5(2), 57-64.

Militaru, Gh. (2015). An exploratory Study of the Impact of Servitization on Customer Perceived Value, Applied Mechanics and Materials.

Nunnally, I.C. (1978). Psychometric Theory. Second Edition, New York, McGraw-Hill.

Rasmussen, E.C \& Sorheim, R. (2006). Action-based entrepreneurship education, Technovation, 26, 185-194.

Schermerhorn, J.R. (2013). Management, Twelfth Edition, Wiley.

Urbig, D., Bürger, R., Patzelt, H., \& Schweizer, L. (2013). Investor reactions to new product development failures: The moderating role of product development stage. Journal of Management, 39(4), 985-1015. 